ヒト毛髪タンパク質と絹フィブロインから成る複合フィルムの作製と性質

\author{
信州大学繊維学部 藤井敏弘・荻原大祐・松岡和法・奈倉正宣
}

\title{
Preparation and Properties of Composite Film Consisting of Human Hair Proteins and Silk Fibroin
}

\author{
Toshihiro Fujii, Daisuke Ogiwara, Kazunori Matsuoka, and Masanobu Nagura
}

Faculty of Textile Science and Technology, Shinshu University, 3-15-1, Tokida, Ueda, Nagano 386-8567, Japan.

\begin{abstract}
The technology of film production is important in the biomedical and cosmetics fields. We have developed convenient procedures for preparing human hair protein film mainly consisting of hard keratins. The mechanical strength of the hair protein films is too weak to use for practical application. Fibroin, a protein fiber synthesized in silkworm, can also form a film with higher mechanical strength. Thus, we prepared the composite films consisting of human hair proteins and silk fibroin. The composite films were translucent and became flexible in a wet state, and they formed a micro phase separation structure, which has each crystal of two protein components. The breaking stress of the composite films was gradually decreased with increasing content of hair proteins. Practical usage seems to be possible when the weight content of hair protein is lower than $70 \%$. The UV-absorption around 270-295 nm wavelength and protease sensitivity of the hair protein film were higher than those of the fibroin film. The composite films exhibited the middle values for UV-absorption. Interestingly, the degradation of the films was dependent on the kinds of proteases used and on the constituent ratio of the two proteins. These results suggest that a simple mixing procedure can control the properties of the protein film including mechanical strength, UV-absorption, and protease sensitivity. Furthermore, the composite film can be customized for individuals, and for such a film the biocompatibility should be considered.

(Received 8 April, 2006 ; Accepted 10 July, 2006)
\end{abstract}

\section{1. 緒 言}

動物や他人由来ではなく, 自己由来の組織要素を原材 料として有用加工品の作製に展開する技術を確立し，さ らに製品化できれば社会にとって大きなプラスになるも のと私たちは考えている.この理由としては, 自己由来 の原料からできた製品を本人が使用するため, 免疫原性 が低いことが期待できる，このため，拒絶反応やアレル ギー反応に関係する様な安全性を求められる製品への適 用が想定できる.これらを“セルフリサイクル製品” と 名付け，「動物や他人由来のものを使わず，自己由来の生 体材料を使用して再利用する製品」と定義している[1-3].

セルフリサイクル製品の原料として，毛髪と爪を第一 に考えている.髪の毛と爪は一生涯にわたり合成されて おり, 余分な毛髪と爪は, 通常不要物質として切られ廃 棄されている持続性のある資源である. 血液, リンパ液 などと比べ採取に負担が少なく, 特に, 毛髪はある程度 まとまった量を集めることが可能である，毛髪と爪の 7080\% は, ケラチンを主成分とするタンパク質で構成され ている、私たちは, 毛髪から簡便にタンパク質を抽出す
る方法を見出し，信大法と名付けた $[1,4]$. 信大法は従来 からの還元抽出法を基本にした方法であるが, 溶液 $\mathrm{pH}$ 8.5 としているため, ケラチンの分解がほとんどない. ま た, 尿素とチ才尿素の組夕合わせであるため, 以前から 使用されていた尿素単独を使用していた方法と比べ，抽 出タンパク質量は 3 倍以上多い. マウスを用いた実験で, 自己由来の毛髪タンパク質に対する抗原性は, 他者由来 よりも1/100-1/200 低いことを報告している [5]. 次に, 毛髪タンパク質フィルムを形成する方法を開発した $[6,7]$. 得られたフィルムは乾燥および湿状態において辛うじて ハンドリングできる程度の力学的な特性であったが, 分 解性を示した $[8]$. ガーゼとの一体化ができたため, この フィルムは皮膚パッチ試験において安全性が高いことを 報告している[7]. しかし，このタンパク質フィルムの力 学的な強度が低いため, 改善する必要がある。

繊維素材の中で, 絹は虫が産出するフィブロインを構 成成分としている. フィブロインは, 高い生体適合性を 利用して縫合糸, 細胞増殖基材, 創傷被覆膜などの医用 や化粧品材料として使用されている. また, その分解物 はサプリメント的な使用が進んできており, 安全性の高 
い天然物質と考えられている.フィブロインはフィルム 化しても実用に耐えうる機械的強度を示し, 高い生体適 合性を示すことが報告されている $[9,10]$.また，Lee らは， 羊毛由来のカルボキシメチル化ケラチンタンパク質に絹 フィブロインを混合したフィルムでは，特に，1:1(重量) のブレンドフィルムにおいてはそれぞれ単独のフィルム と比べ血栓形成能が約 $50 \%$ に減少することを報告してい る $[11]$.

このため, ヒト由来の毛髪タンパク質と絹フィブロイ ンを混合してフィルム形成すれば，お互いの長所を備え たフィルムとなることが考えられる。本研究では, 優れ た生体適合性をもつフィブロインと混合した複合型の毛 髪タンパク質フィルムを作製し, その力学的評価, 構造, 成分分析とプロテアーゼ感受性について検討を行った.

\section{2. 実 験}

\section{1 タンパク質の調製とフィルム作製}

複数のボランティアから採取した毛髪は, エタノール で洗浄して室温下で保存した。毛髪タンパク質は信大法 溶液 (5 M 尿素, $2.6 \mathrm{M}$ チ才尿素, $5 \%$ 2-メルカプトエタノー ル， $25 \mathrm{mM}$ Tris-HCl, pH 8.5)により $50^{\circ} \mathrm{C}, 3$ 日間抽出した 後, 蒸留水に透析した $[4]$. 絹フィブロイン溶液は, 絹ブー レットを $65 \%$ 塩化カルシウムとエタノール $(5: 2)$ の混合 溶液を加え, 沸騰水浴中で調製した。この溶液をろ過し, 蒸留水に透析した. タンパク質量は, Bradford 法にて測 定した[12].

蒸留水に対し透析したヒト毛髪タンパク質 (30-50 mg/ $\mathrm{ml})$ と絹フィブロイン $(30-50 \mathrm{mg} / \mathrm{ml})$ を各比率で加え, 1 時 間振動し混合した。この溶液をテフロン板あるいはシャー レにキャストし, 室温下で自然乾燥させフィルムを作製 した.

フィルムからタンパク質の溶出を防ぐため, 各フィル ムを $70 \%$ エタノールに約 1 時間浸すことによりエタノー ル処理を行った。

\section{2 電気泳動}

SDS-ポリアクリルアミド電気泳動は, Laemmli の方法 に従い行った[13]. $6 \mathrm{M}$ 尿素を含む $5 \%$ と $8 \%$ アクリルア ミドゲルを使用した。染色は, クマシー・ブリリアント ブルーR-250により行った.

\section{3 引張り試験}

試料はエタノール処理をした後, $37^{\circ} \mathrm{C}$ の蒸留水で 1 時 間膨潤させ，マイクロダンベルで成型し，Toyo baldwin 社 製引張り試験機 (Tensilon U- II-20)を用い，測定を行った. 毛髪タンパク質 $80 \%, 100 \%$ の試料は, 強度が弱すぎて測 定不能であったので, これ以外の試料を測定し, 破断強 度と破断伸度を以下の式を用いて算出した。

試料の厚さはマイクロメーターで測定し， $5 \mathrm{~mm}$ 幅の試 料を用い, 各々の試料の断面積 $\mathrm{S}\left(\mathrm{m}^{2}\right)$ を求めた. 5 回測定

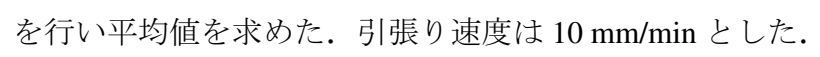

$$
\begin{gathered}
\text { Strength }(\mathrm{Pa})=\left(\mathrm{N} / \mathrm{m}^{2}\right)=\mathrm{W}(\mathrm{kg}) \times 9.81 / \mathrm{S}\left(\mathrm{m}^{2}\right) \\
\text { Elongation }(\%)=\mathrm{L}_{1}(\mathrm{~mm}) / \mathrm{L}_{0}(\mathrm{~mm}) \times 100
\end{gathered}
$$

\section{4 動的粘弾性測定}

アイテイ計測制御(株)製の温度コントロール型動的粘 弾性装置 (DVA-225) を用い, 温度範囲は $100-300^{\circ} \mathrm{C}$, 昇温 速度は $10^{\circ} \mathrm{C} / \mathrm{min}$ で測定した。

\section{5 広角 $X$ 線回折測定}

理学電気工学(株) 製ゴニオメーター(PMG-GAN215505) を用い，管電圧 $40 \mathrm{kV}$ ，管電流 $150 \mathrm{mV}$ で測定を行った. 回折角範囲は $2 \theta=2-30^{\circ}$, スキャン速度 $0.5^{\circ} / \mathrm{min}$, スキャ ン間隔 $0.01^{\circ}$ とした.

\section{6 タンパク質フィルムの分解}

フィルムの分解は, TBS 緩衝液 (20 mM Tris- $\mathrm{HCl}, 140 \mathrm{mM}$ $\mathrm{NaCl}, \mathrm{pH} 7.5)$ 中で, $1 / 10(\mathrm{wt} / \mathrm{wt})$ の比で各プロテアーゼ $(0.3-$ $0.5 \mathrm{mg} / \mathrm{ml})$ と混合し, $37^{\circ} \mathrm{C}$ でインキュベーションした. サンプルは, $10.000 \mathrm{~g}, 5$ 分閒遠心後, 得られた沈渣を蒸 留水で洗浄した. この操作を 4 回繰り返し, 乾燥後の凝 集体の質量を測定し分解率をもとめた.

\section{3. 結果と考察}

(A)

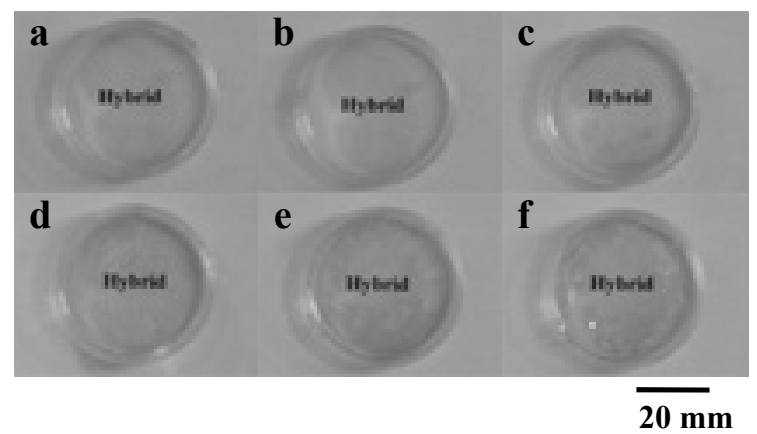

(B) Hybrid films $\begin{array}{cccccccc}\text { Hair protein content }(\%) \\ \text { SF } & \text { HP } & 0 & 20 & 40 & 60 & 80 & 100\end{array}$

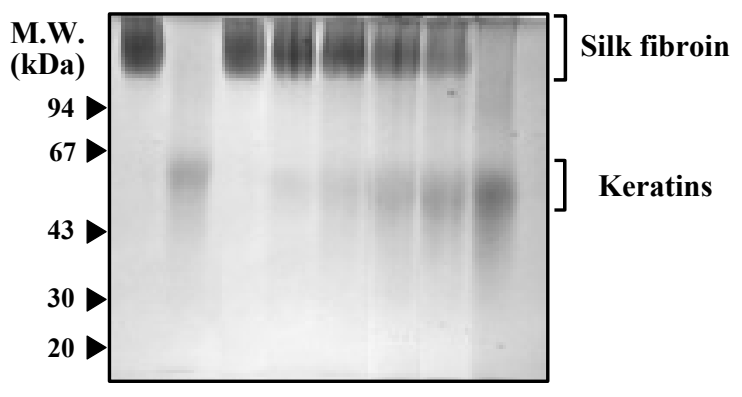

Fig. 1 Photographs (A) and protein components (B) for the composite films consisting of human hair proteins and silk fibroin : a, silk fibroin; b, hair protein $20 \%$; c, hair protein $40 \%$; d, hair protein $60 \%$; e, hair protein $80 \%$; f, hair protein.

Proteins were analyzed with $8 \%$ polyacrylamide gel containing $6 \mathrm{M}$ urea : SF, silkfibroin ; HP, hair proteins. 


\section{1 フィルムの形態観察と構成タンパク質の分析}

ヒト毛髪タンパク質および絹フィブロイン水溶液を シャーレにキャスティングし, 室温下で乾燥させると半 透明なフィルムが形成される. 毛髪タンパク質フィルム は薄い茶色を帯び半透明である. 一方, フィブロインフィ ルムは僅かに黄色みを帯びているが透明性が高かった。 ブレンドフィルムは, 毛髪タンパク質混合量が増加する に従い, 絹フィブロインの薄い黄色から茶色の色合いと なった(Fig. 1A).

ヒト毛髪タンパク質と絹フィブロインの複合フィルム を信大法溶液-9 M 臭化リチウム混合 $(1: 1)$ 溶液によりタ ンパク質を再抽出し, 電気泳動を行った (Fig. 1B). 毛髪 タンパク質の主成分であるケラチン $(40-60 \mathrm{kDa})$ のバンド は同定できたが，低分子量成分であるマトリックスタン パク質は確認できなかった.フィブロインは $120 \mathrm{kDa}$ 以 上を示す太いバンドとして見出された。これを $6 \mathrm{M}$ 尿素/ $5 \%$ ポリアクリルアミドゲル電気泳動で分析したところ, 120-200 kDa と幅広い分子量の範囲で染色されたことから, 複数のポリペプチドから成っていることが示された. 次 に，ブレンドフィルムは毛髪タンパク質とフィブロイン 由来のバンドがともに含まれており, その割合はフィル ムの混合比に依存して変化した。これらのことは, 数ヶ 月間室温で保存しておいたフィルムでも見られることか ら, 両タンパク質は安定に存在していることが示唆され た.

\section{2 乾燥フィルムの構造と物性}

Fig. 2 に, エタノール処理をほどこす前後のブレンド フィルムの広角 $\mathrm{X}$ 線回折強度曲線を示した. 毛髪タンパ ク質 0-60\%の試料では，エタノール処理前は非常に幅の 広いピークしか見られなかったが(Fig. 2A), エタノール 処理後には散乱角 $2 \theta=20.5^{\circ}$ 付近と $24^{\circ}$ 付近に, 新たな ピークが出現した (Fig. 2B)。この新たなピークは, 絹フィ ブロインの $\beta$-sheet 構造を有する silk II 型結晶に特徵的な 回折ピークで，エタノール処理によって結晶性が低い絹 フィブロインが結晶化することが示された. 毛髪タンパ ク質含有率が $50 \%$ を超えると, 未エタノール処理試料で は $2 \theta=10^{\circ}$ 付近と $19.5^{\circ}$ 付近に, 絹フィブロインの結晶回 折ピークとは異なるピークが見られた. $2 \theta=10^{\circ}$ 付近の ピークは毛髪タンパク質結晶内の $\alpha$-helix 間の周期に相当 し, $2 \theta=19.5^{\circ}$ 付近のものは, $\alpha$-helix 構造が羊毛繊維と類 似のいわゆる coiled coil 構造をとっていると推測される [14].これらのピークがエタノール処理によって若干強 度が増すことから, 毛髪タンパク質の結晶性は増加した と考えられる。

更なるエタノール処理後, 絹フィブロイン単独フィル ムの最大ピークは $2 \theta=20.5^{\circ}$ で, 毛髪タンパク質の割合の 増加に伴ってピークの位置が低角度側にシフトしていき, 毛髪タンパク質 $100 \%$ の試料は $2 \theta=19.5^{\circ}$ の值を示した. これは, 高角度側の絹フィブロインと低角度側の毛髪タ ンパク質の両者の回折ピークが重なり合い, 混合割合に
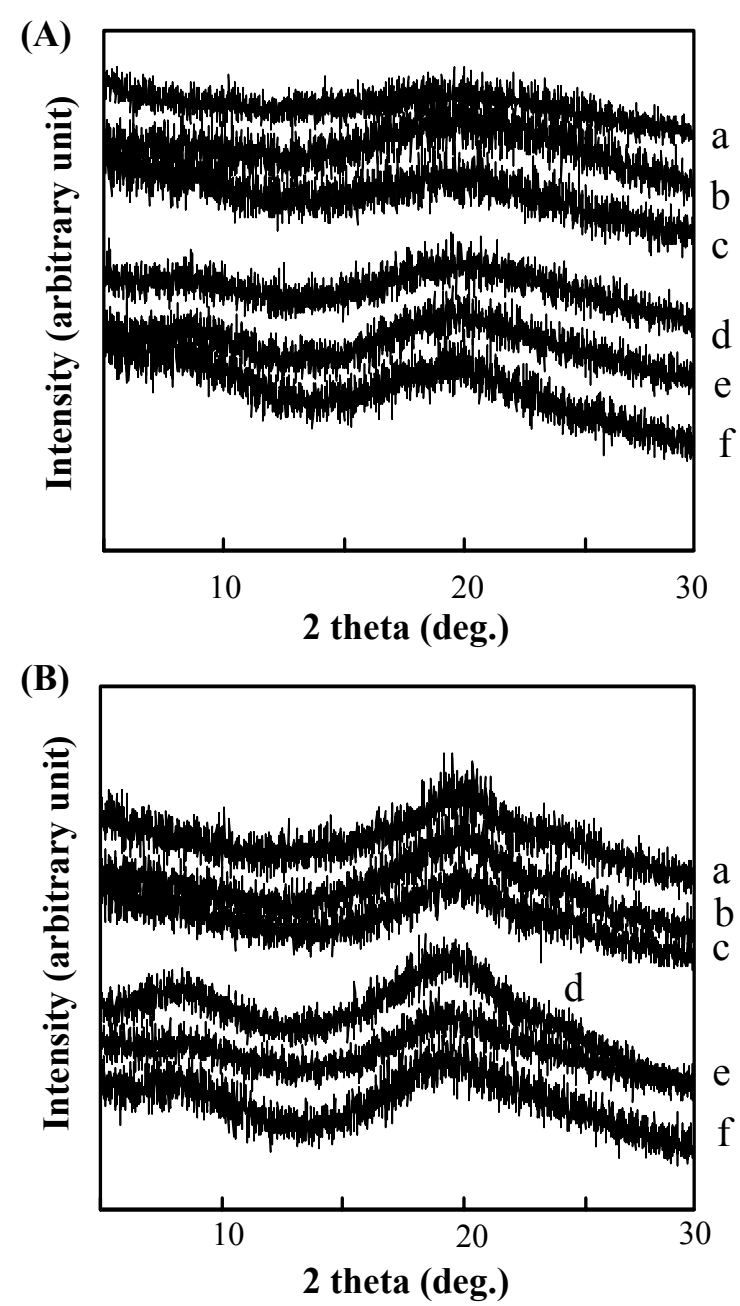

Fig. 2 Wide-angle X-ray scattering intensity profiles of untreated $(A)$ and ethanol-treated $(B)$ hair proteins -silk fibroin films : a, silk fibroin ; b, hair protein $20 \%$; c, hair protein $40 \%$; d, hair protein $60 \%$; e, hair protein $80 \%$; f, hair protein.

応じてピークの位置が移動したためと考えられる.

上記のことから，絹フィブロインと毛髪タンパク質は, ブレンドすることにより各々の結晶構造を変えることな く独立に存在していることが分かる. 即ち, 絹フィブロ インと毛髪タンパク質がミクロに相分離しているフィル ムであることが示唆された。

$\mathrm{X}$ 線回折の結果の妥当性を更に検討し, 相分離構造で ある事を確認するために動的粘弾性の測定を行った. Fig. 3 に, エタノール処理をほどこす前と後のブレンドフィル ムの貯蔵弾性率 $\left(\mathrm{E}^{\prime}\right)$ の温度変化を示した。絹フィブロイ ンの $\mathrm{E}^{\prime}$ は $180^{\circ} \mathrm{C}$ 付近で一旦低下後, 再び増加し, 次いで $270^{\circ} \mathrm{C}$ 付近で急激に低下していた (Fig. 3A). 毛髪タンパク 質の $\mathrm{E}^{\prime}$ は, $210^{\circ} \mathrm{C}$ 付近から急激に下がっていた. 絹フィ ブロインのガラス転移温度が $175^{\circ} \mathrm{C}$ 付近にあることから [15], 絹フィブロインの $180^{\circ} \mathrm{C}$ 付近の変化は, 非晶分子 が運動を開始することにより E’が低下し, 次いで非晶鎖 の結晶化により E’が増加することを示していた．絹フィ ブロインの $270^{\circ} \mathrm{C}$ 付近と毛髪タンパク質の $210^{\circ} \mathrm{C}$ 付近か 
(A)

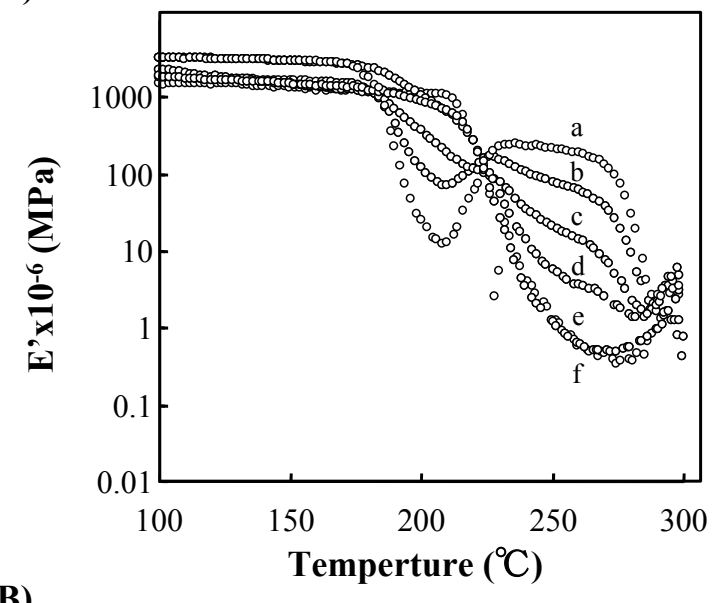

(B)

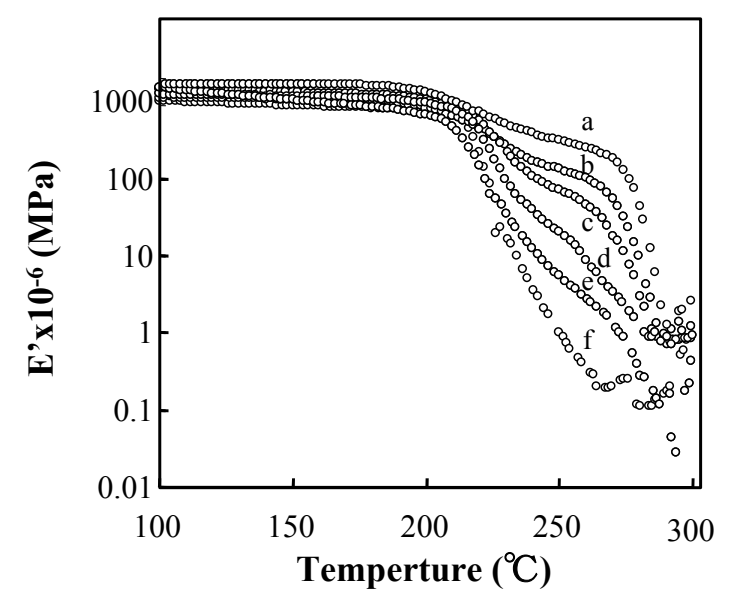

Fig. 3 Temperature dependence of dynamic storage modulus of untreated (A) and ethanol-treated (B) hair proteins-silk fibroins : a, silk fibroin; $b$, hair protein 20\%; c, hair protein $40 \%$; d, hair protein $60 \%$; e, hair protein $80 \%$; f, hair protein.

らの $\mathrm{E}^{\prime}$ の低下は, 測定後の試料が炭化していることから, 分解によるものと考えられる.

エタノール処理フィルムの $\mathrm{E}^{\prime}$ の温度変化から, 絹フィ ブロインの $180^{\circ} \mathrm{C}$ 付近にあった $\mathrm{E}^{\prime}$ の低下が無くなってい た(Fig. 3B).X線回折のデータから, エタノール処理に より非晶部は $\beta$-sheet を含む silk II 型結晶に変化している ことを考慮すれば，非晶鎖の運動の開始と結晶化が既に 終了していることがこの原因と考えられる. シルクの 270 ${ }^{\circ} \mathrm{C}$, 毛髪タンパク質の $210^{\circ} \mathrm{C}$ の急激な $\mathrm{E}$ 'の低下について は, 未エタノール処理フィルムと同様に考えて良いと言 える．これらのブレンドフィルムの $\mathrm{E}^{\prime}$ の結果は，X線回 折における結果と一致し, 絹フィブロインと毛髪タンパ ク質が結晶を含み, 結晶部はミクロに相分離しているこ とを示唆した.

乾燥フィルムの光吸収特性を検討するために, 石英板 上にフィルムを作製し，260-400 nm の UV 吸収スペクト ル測定を行った(Fig. 4). 各フィルムは $310 \mathrm{~nm}$ 以下の波 長で吸収が見られ，280 $\mathrm{nm}$ 付近にピークを示した。毛髪 タンパク質含有量が高いフィルムほど吸光度が高くなる

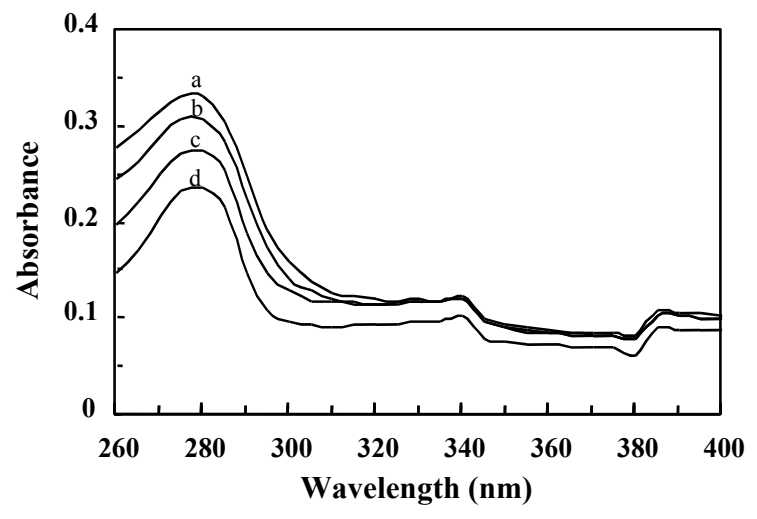

Fig. 4 UV-spectrometry of the hair protein-silk fibroin films. The summation of the amount of hair protein and silk fibroin was $0.3 \mathrm{mg} / \mathrm{cm}^{2}$ : a, hair proteins ; b, hair protein $80 \%$; c, hair protein $40 \%$; d, silk fibroin.

傾向が見られた。これは，チロシンを除いて，シスチン， フェニルアラニン, ヒスチジンの含量が, フィブロイン よりも毛髪タンパク質で高いことによっているものと思 われる $[11,16]$. 特に, UV-B $(290-329 \mathrm{~nm})$ と UV-C $(100-290$ $\mathrm{nm})$ の領域の紫外線を強く吸収するため, 低波長紫外線 の吸収材となることが期待される.

\section{3 含水状態の物性}

エタノール未処理試料は毛髪タンパク質の湿潤による 溶出が激しく, 引っ張り試験を行うには弱すぎるもので あった。一方，エタノール処理試料は Fig. 2 でわかるよう に明らかに結晶性が増大し, その結果, 溶出が抑えられ 引っ張り試験が可能であった. エタノール処理ブレンド フィルムの破断強度と破断伸度を, 湿潤環境下での引っ 張り試験により測定した (Fig. 5). 絹フィブロインを $100 \%$ 含むフィルムの破断強度が最も高い值で, 約 $4.5 \mathrm{MPa}$ で あった。これは, 報告されている值と比較して, むしろ 高い值を示した[17]. 毛髪タンパク質を $25 \%$ まで含む複 合フィルムの破断強度は, 絹フィブロインフィルムとほ とんど変わらない值を示した。ささらに毛髪タンパク質混 合比率を増加させると, 破断強度が下がり, 毛髪タンパ

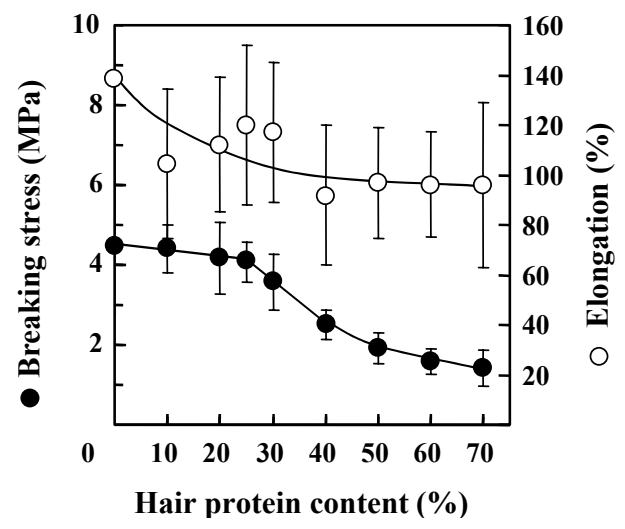

Fig. 5 Tensile properties of the hair proteins-silk fibroin films. 
ク質が 40-50\%を占めると， 2-2.5 MPa と約 $1 / 2$ まで低下 した。毛髪タンパク質混合比率が $70 \%$ を超えると破断強 度が著しく低下し, フィルム自体の取り扱いが困難となっ た. 破断伸度は, 毛髪タンパク質が $10 \%$ 以上含まれるフィ ルムではフィブロイン単独フィルムよりも $20-25 \%$ 低下し た.

破断強度が毛髪タンパク質分率 $25 \%$ までほとんど変化 しなかったのは，「3.2」項で考察したように，毛髪タンパ ク質と絹フィブロインはミクロに相分離しているが，こ の範囲までは両者の非晶鎖間での相互作用が可能である ためと示唆された.

\section{4 フィルムのプロテアーゼ感受性}

フィルムは, 医療や美容の分野での使用を想定してい るため, 生分解性は特性の一つといえる. そこで, in vitro の条件下での各種プロテアーゼ処理の感受性を調べた. 毛髪タンパク質溶液とそのフィルムが，トリプシン，キ

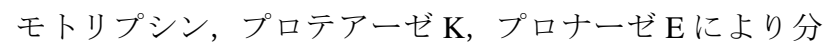
解を受けることを報告している $[8]$. 一方, フィブロイン シートおよびファイバーは，コラゲナーゼなどのプロテ アーゼによる分解性が調べられている [18-20]. 多くのタ ンパク質と比べ, フィブロインの分解には高濃度のプロ

(A)

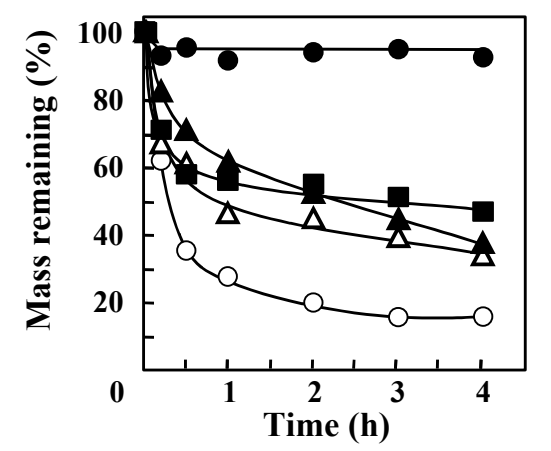

(B)

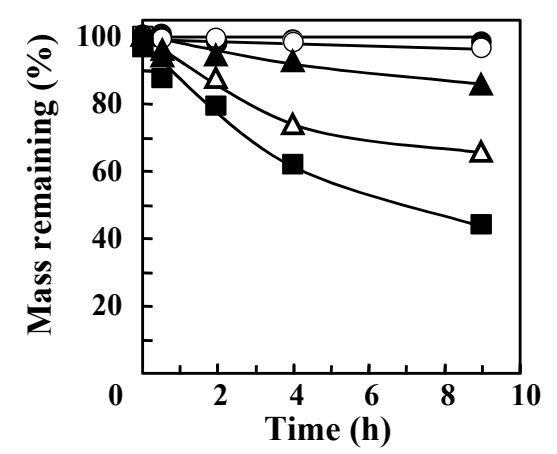

Fig. 6 Degradation rate of the hair protein (A) and silk fibroin (B) films by various Proteases. Hair proteins and silk fibroin films were incubated without protease (O) and with $1 / 10$ (wt/wt) trypsin $(\bigcirc)$, chymotrypsin $(\triangle)$, pronase $\mathrm{E}(\boldsymbol{\Delta})$, and protease XIV $(\boldsymbol{\square})$ at $37^{\circ} \mathrm{C}$ for $0-4 \mathrm{~h}$. The quantities of protein recovered as films were calculated by weighing.
(A)

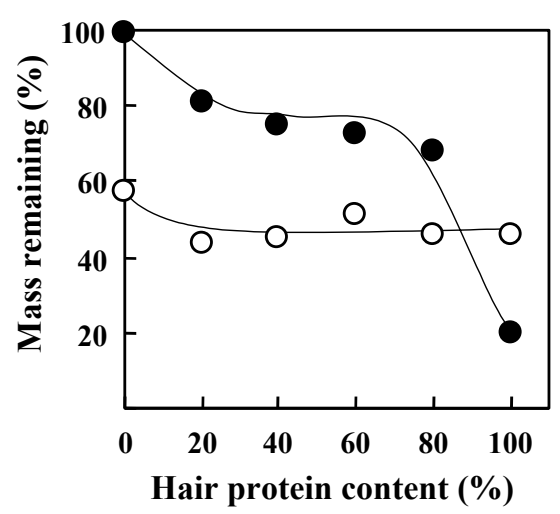

(B) Hair protein content (\%)

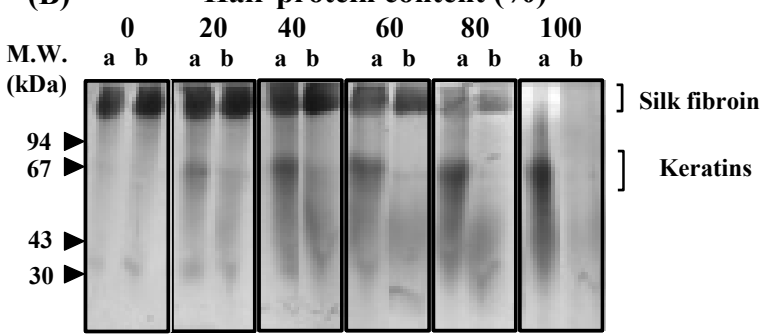

(C) Hair protein content (\%)

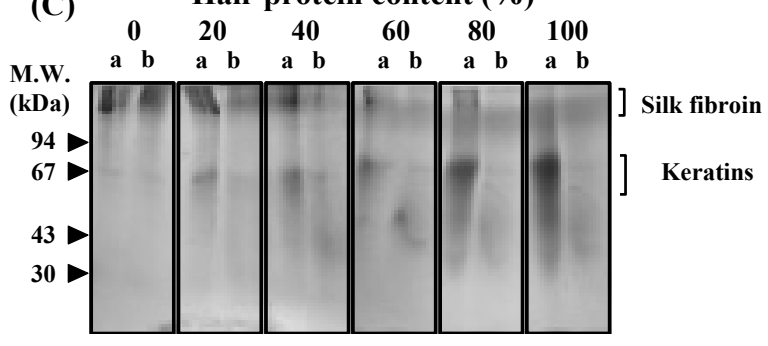

Fig. 7 Degradation of the composite films with trypsin and protease XIV. Degradation rate of the composite films by trypsin $(O)$ and protease XIV (O) was calculated by weighing (A), and the protein components after treatment with trypsin (B) and protease XIV (C) were analyzed with $8 \%$ polyacrylamide gel containing $6 \mathrm{M}$ urea. a, Untreated film ; b, treated film.

テアーゼと数日にもおよぶ長時間の反応を必要としてい た.

毛髪タンパク質あるいはフィブロインから作られた フィルムへのトリプシン, キモトリプシン, プロナーゼ E，プロテアーゼ XIV による分解性を調べた (Fig. 6). 本 実験条件下では, トリプシンは毛髪タンパク質フィルム をよく分解するが，フィブロインフィルムへの分解作用 はほとんど見られなかった. キモトリプシンについては， 毛髪タンパク質フィルムを分解するが, フィブロインフィ ルムへは $10 \%$ とわずかな分解にとどまった. プロナーゼ E とプロテアーゼXIV は，両フィルムを分解した． 特に, プロテアーゼ XIV のフィブロインフィルムへの分解作用 が大きいことが示された.

このため, トリプシンとプロテアーゼ XIVを用い，4 
時間のインキュベーションによるブレンドフィルムへの 分解性を調ベた (Fig. 7). トリプシンの場合は, 毛髪タン パク質含量が増加するにともない, そのフィルム重量は 減少した. 電気泳動の結果, ケラチンの分解は見られる がフィブロインは残存していた (Fig. 7B). 毛髪タンパク 質の割合が $80 \%$ のフィルムにおいてもその形状が残って いたことから，フィルム形状がフィブロインによって保 たれていることが示された.これらの傾向は, キモトリ プシンとプロナーゼ $\mathrm{E}$ の場合においても見られた. 次に, プロテアーゼ XIV の場合は, 約 40\% の絹フィブロイン単 独フィルムの重量を減少させるが, フィルム形状は保っ ており, 電気泳動においてもフィブロインのバンドは確 認できた(Fig. 7C). フィブロイン含量が少ないブレンド フィルムにおいては，ピンセットで軽く接触しても壊れ る脆弱なフィルムとなった。

Li らは，本実験条件と同様に，プロテアーゼ XIV を使 用してフィブロインシートを $1 \mathrm{unit} / \mathrm{ml}, 37^{\circ} \mathrm{C}$ 下で反応さ せたところ, 分解が始まるには 5 日以上のインキュベー ションが必要であると報告している $[18]$. 一方, 本研究 での実験条件も $0.2 \mathrm{mg} / \mathrm{ml}$ (1 unit/ml)のプロテアーゼ XIV を使用しているが, 4 時間のインキュベーションで 30-40\% のフィルム重量が減少する結果が得られた。これは, 原 料となる絹自体, フィブロインの分子種, およびフィル ムの厚さなどが関係しているものと考えられる。毛髪夕 ンパク質と絹フィブロインの混合比によりプロテアーゼ 感受性が異なるフィルムとなることが示された.

\section{4. まとめ}

本研究において :

1. 毛髪タンパク質と絹フィブロインを混合することに より, (1) 機械的強度, (2) 分解性, (3) 紫外領域の吸収 の 3 点を調整できるフィルム作製が可能である.

2. 混合フィルムでは, 両者の結晶領域が独立に存在し, ミクロ相分離構造を形成する.

3. 混合フィルムは, 一度合成され, 採集可能な毛髪か らのタンパク質と優れた生体適合性を有するフィブ ロインを原材料としているため, 個人由来の組織を 含む安全性の高いフィルムとなり，医用材料や化粧 品の分野での利用が期待できる.
謝 辞

本研究の一部は, 文部科学省科学研究費補助金 $(\mathrm{COE}$ 形 成基礎研究費; 10CE2003, 基盤研究 B；16350123）とコス メトロジー研究振興財団の助成を受けた. 絹ブーレット は, 平出真一郎氏から供与を受けた。 また, 英文は Mike Honywood 氏の協力を得た。 ここに深く感謝いたします.

\section{文 献}

1. T. Fujii, Bio Industry, 19, 22-27 (2002).

2. S. Kobayashi and T. Fujii, Jour. Jpn Soc. Mech. Eng., 1047, 121 (2006).

3. T. Fujii and S. Kobayashi, Nippon Keshohin Gakkaishi, 30, 1 (2006).

4. A. Nakamura, M. Arimoto, K. Takeuchi, and T. Fujii, Biol. Pharm. Bull., 25, 569 (2002).

5. Y. Ide and T. Fujii, Sen'i Gakkaishi, 60, 276 (2004).

6. T. Fujii, D. Ogiwara, and M. Arimoto, Biol. Pharm. Bull., 27, 89 (2004).

7. T. Fujii and Y. Ide, Biol. Pharm. Bull ., 27, 1433 (2004).

8. Y. Ide and T. Fujii, Kobunshi Ronbunshu, 61, 190 (2004).

9. H. Mori and M. Tsukada, Rev. Molec. Biotech., 74, 95 (2000).

10. G.H. Altman, F. Diaz, C. Jakuba, T. Calabro, R.L. Horan, J. Chen, H. Lu, J. Richmond, and D.L. Kaplan, Biomaterials, 24, 401 (2003).

11. K.Y. Lee, S.J. Kong, W.H. Park, W.S. Ha, and I.C. Kwon, J. Biomater. Sci. Polymer Edn., 9, 905 (1998).

12. M.M. Bradford, Anal. Biochem., 72, 248 (1976).

13. U.K. Laemmli, Nature, 227, 680 (1970).

14. H. Sakabe, T. Miyamoto, and H. Inagaki, Sen'i Gakkaishi, 37, T-273 (1981).

15. M. Nagura, K. Gotoh, and H. Ishikawa, Kobunshi Ronbunnshu, 34, 389 ( 1977).

16. F. -J. Wortmann, G. Wortmann, and H. Zahan, Text. Res. $J ., 65,669$ (1995).

17. S. Hirade, J. Seric. Sci. Jpn ., 66, 138 (1997).

18. M. Li, M. Ogiso, and N. Minoura, Biomaterilas, 24, 357 (2004).

19. T. Arai, G. Freddi, R. Innocenti, and M. Tsukada, J. Appl. Polym. Sci., 91, 2383 (2004).

20. R. L. Horan, K. Antle, A.L. Collette, Y. Wang, J. Huang, J. E. Moreau, V. Volloch, D.L. Kaplan, and G.H. Altman, Biomaterials, 26, 3385 (2005). 